\title{
PENGARUH PEMECAHAN MASALAH TERHADAP PENINGKATAN HASIL BELAJAR SENAM ARTISTIK
}

\author{
Pamuji Sukoco \\ FIK Universitas Negeri Yogyakarta (e-mail: psukoco@yahoo.co.id; \\ HP: 08156804774)
}

\begin{abstract}
The Contributions of Problem Solving on the Improvement of Artistic Gymnastics Learning Outcomes. This study aims to improve the psychomotor skills in artistic gymnastics and cognitive skills of the students of Physical Education, Health, and Recreation (PEHR), Faculty of Sports Sciences, Yogyakarta State University in the academic year of 2008/2009 through the problem-solving learning strategy. This was an action research study involving two cycles. The subjects were the students of the non-regular PEHR program. The data were analyzed using the quantitative descriptive technique. The results showed that the learning approach to artistic gymnastics using the problem-solving learning strategy was capable of improving the psychomotor and cognitive skills indicated by the artistic gymnastics learning outcomes with a mean of 7.02.
\end{abstract}

Keywords: problem solving, learning outcomes, artistic gymnastics

\section{PENDAHULUAN}

Senam artistik merupakan bagian dari mata kuliah Dasar Gerak Senam. Gerakan dalam senam artistik cukup rumit dan kompleks. Menurut keterampilan geraknya, senam dapat diklasifikasikan ke dalam keterampilan diskrit dan serial. Menurut Mahendra (2001: 29), senam merupakan kegiatan fisik yang paling kaya struktur gerak. Kekompleksan gerakan dalam senam artistik tersebut memerlukan waktu yang cukup lama untuk menguasainya atau dapat melakukannya. Oleh karena itu, dalam proses pembelajaran harus mampu memberi kesempatan pada mahasiswa untuk belajar menguasai keterampilan gerak dalam senam.

Selama ini, proses pembelajaran senam artistik masih menggunakan pen- dekatan atau metode konvensional. Pendekatan atau metode yang digunakan menggunakan metode ceramah, demonstrasi dan latihan (drill). Dosen memberi penjelasan dan contoh (demonstrasi) tentang teknik keterampilan yang ada dalam senam artistik, mahasiswa memperhatikan dan melaksanakan latihan senam artistik. Evaluasi pelaksanaan pembelajaran didominasi oleh dosen. Mahasiswa memperoleh kesempatan mengevaluasi tidak bisa secara keseluruhan karena hanya yang ditunjuk oleh dosen. Dengan cara ini, kesempatan belajar dalam menganalisis gerakan mahasiswa menjadi kurang. Hanya mahasiswa yang ditunjuk yang memperoleh kesempatan berpikir analitis. 
Kemampuan mahasiswa dalam menganalisis teknik gerakan ini sangat diperlukan di masa mendatang ketika mengajar senam. Mahasiswa Prodi PJKR merupakan mahasiswa yang disiapkan menjadi tenaga profesional sebagai guru bidang studi Pendidikan Jasmani, Olahraga dan Kesehatan (Penjasorkes). Sebagai calon guru Penjasorkes, mereka harus dibekali kemampuan untuk menganalisis teknik gerakan dalam seluruh cabang olahraga, termasuk senam artistik. Kekompleksan gerakan dalam senam artistik menuntut para calon guru Penjasorkes menggunakan kemampuan berpikirnya untuk menganalisis teknik gerakan sehingga mampu memberikan bimbingan dan bantuan, pengarahan, mengoreksi dan mengevaluasi teknik gerak tersebut di masa mendatang dalam tugas sebagai guru Penjasorkes. Berdasarkan arsip nilai senam artistik, nilai mahasiswa dalam menempuh matakuliah senam artistik dari tahun ke tahun kurang menggembirakan. Hal tersebut dapat dilihat dalam Tabel 1 berikut.

\section{Tabel 1: Daftar Nilai Matakuliah Senam Artistik Prodi PJKR Kelas B}

\begin{tabular}{lccccccccccc}
\hline & & \multicolumn{7}{c}{ Nomlah Mahasiswa Yang Mendapat Nilai } \\
\cline { 4 - 11 } No & Tahun & Jml Mhs & A & A- & B+ & B & B- & C+ & C & D \\
\hline 1 & 2003 & 42 & & 2 & 2 & 6 & 4 & 14 & 5 & 10 \\
2 & 2004 & 44 & 1 & 1 & 4 & 10 & 2 & 12 & 6 & 8 \\
3. & 2005 & 43 & & 2 & 3 & 8 & 4 & 14 & 4 & 8 \\
4. & 2006 & 46 & & 3 & 1 & 5 & 6 & 16 & 3 & 12 \\
5. & 2007 & 45 & 1 & 2 & 2 & 4 & 4 & 17 & 4 & 11 \\
\hline
\end{tabular}

Sumber: Arsip Nilai Dari Dosen Matakuliah Dasar Gerak Senam

Berdasarkan data hasil penilaian dari tabel di atas, dapat diketahui bahwa masih terdapat nilai $C$ dan $D$ yang cukup besar persentasenya. Oleh karena itu, perlu diupayakan peningkatan hasil pembelajaran dasar gerak senam bagi mahasiswa PJKR, Khususnya Kelas B.

Menurut Moston (Dauer dan Pangrazy, 1997:68), guru dapat melaksanakan proses pembelajaran dengan berbagai macam pendekatan gaya mengajar. Terdapat 9 gaya mengajar yang dijelaskan oleh Moston. Salah satu gaya mengajar yang dijelaskan oleh Moston dalam pembelajaran Penjasorkes adalah gaya mengajar pemecahan masalah (problem-solving style). Gaya mengajar pemecahan masalah memiliki karakteristik yang dapat mengaktifkan mahasiswa dan dosen dalam setiap kegiatan pembelajaran. Gaya mengajar pemecahan masalah memberi kesempatan mahasiswa untuk merancang dan mengevaluasi belajar gerak senam. Mahasiswa menjadi lebih aktif dalam belajar dan memperoleh bimbingan belajar, termasuk di dalamnya memperoleh kesempatan menganalisis gerak, mengoreksi, dan mengevaluasi. Di samping itu, mahasiswa juga memperoleh kesempatan melakukan ulangan gerakan dalam belajar senam. 
Dengan pendekatan gaya mengajar pemecahan masalah, diharapkan dapat meningkatkan penguasaan keterampilan teknik gerak pada senam artistik dan kemampuan kognitif mahasiswa dalam merancang menganalisis, mensintesis, dan mengevaluasi pembelajaran senam sehingga dapat berkembang dan meningkat. Atas dasar uraian tersebut di atas, perlu dilakukan penelitian pembelajaran senam artistik dengan gaya mengajar pemecahan masalah sebagai upaya meningkatkan kemampuan kognitif dan hasil belajar matakuliah senam artistik Prodi PJKR Kelas B FIK UNY. Indikator keberhasilan proses pembelajaran adalah peningkatan nilai senam artistik atau meningkatnya kemampuan kognitif mahasiswa dalam merancang, menganalisis, mensintesis, dan mengevaluasi pembelajaran senam.

Penelitian ini bertujuan untuk meningkatkan kualitas pembelajaran matakuliah senam artistik Prodi PJKR FIK UNY, dalam arti: (1) meningkatkan kemampuan kognitif dalam merancang, menganalisis, mensintesis, dan mengevaluasi pembelajaran senam; (2) hasil belajar yang berupa keterampilan gerak senam mahasiswa PJKR juga meningkat.

Ganong (1999:62) mendefinisikan belajar sebagai kemampuan mengubah perilaku berdasarkan pengalaman dan mengingat kembali peristiwa-peristiwa sebelumnya pada tingkat sadar atau di bawah sadar. Belajar mencakup perubahan respon terhadap rangsang. Beberapa penulis percaya bahwa memori disebabkan oleh beberapa perubahan secara fisik, atau jejak ingatan (memory trace) pada sistem syaraf yang dihasil- kan dari belajar. Apapun bagian dari otak yang terlibat dalam belajar, beberapa perubahan secara fisik secara logis terjadi pada synapes, situs anatomisnya adalah satu neuron merangsang neuron yang lain. Pendapat Leukel (1968:364) tentang belajar menyatakan bahwa: If it can be shown that learning changes occur at synapses between nerve cells (whatever parts of brain are involved), what is the nature of synaptic changes? "Molar" changes are discused first. Jika dapat diamati, belajar adalah perubahan yang terjadi pada synapes antara selsel syaraf (apapun bagian otak yang terlibat).

Menurut Ganong (1999:106), perubahan-perubahan jangka panjang pada fungsi synapes dapat terjadi akibat riwayat suatu impuls di synapes; artinya hantaran synapestik dapat diperkuat atau diperlemah sesuai pengalaman masa lalu. Perubahan-perubahan tersebut sangat menarik karena jelas mewakili berbagai bentuk proses belajar dan dan daya ingat. Perubahan-perubahan tersebut meliputi potensiasi posttetanik, habituasi, dan sensitisasi.

Potensiasi posttetanikyaitu terbentuknya potensial postsinapstik yang diperkuat sebagai jawaban terhadap rangsang. Penguatan ini berlangsung sampai 60 detik dan terjadi setelah perangsangan tetanik singkat pada neuron presinaptik. Habituasi yaitu apabila rangsang lemah diberikan berulangulang, maka respons terhadap rangsang tersebut lama-kelamaan akan hilang. Dapat bersifat jangka pendek, atau dapat berlangsung dalam waktu lama bila rangsang lemah itu sering diberikan berulang-ulang kali. Sensitisasi ada- 
lah respons posinaptik yang kuat yang berlangsung lama sebagai jawaban terhadap suatu rangsang. Rangsang tersebut merupakan rangsang yang telah terhabituasi, yang satu kali atau beberapa kali dipasangkan dengan rangsang berbahaya.

Belajar gerak disebut juga belajar motorik atau 'motor learning'. Schmidt (1998:346) mendefinisikan; motor learning is a set of processes associated with practice or experience leading to relatively permanent changes in the capability for responding. Belajar motorik adalah seperangkat proses yang bertalian dengan latihan atau pengalaman yang mengantarkan ke arah perubahan permanen dalam perilaku terampil. Definisi ini merupakan sintesis dari konsep belajar pada umumnya. Konsep belajar tersebut menyangkut empat aspek. Pertama, belajar diartikan sebagai seperangkat peristiwa, kejadian, atau perubahan yang terjadi apabila seseorang berlatih yang memungkinkan mejadi semakin terampil dalam melaksanakan kegiatan. Kedua, belajar adalah hasil langsung dari praktek atau pengalaman. Ketiga, belajar tidak dapat diukur secara langsung karena proses yang meng antarkan pencapaian perubahan perilaku berlangsung secara internal atau dalam diri manusia sehingga tak dapat diamati, kecuali ditafsirkan berdasarkan perubahan perilaku. Keempat, belajar dipandang sebagai proses yang menghasilkan perubahan relatif permanen dalam keterampilan; perubahan dalam perilaku yang menyebabkan perubahan pada suasana emosi, motivasi, atau keadaan internal tidak dianggap sebagai akibat belajar. Pandangan ini bertendensi menganut aliran behaviorisme.

Rusli (1988:122) mengklasifikasikan teori belajar gerak berdasarkan pendekatan psikologis dibagi menjadi dua kategori utama, yaitu kelompok teori asosiasi stimulus-respon dan kelompok teori gestalt-field atau teori kognitif. Belajar menurut kelompok teori kognitif adalah siswa mengorganisasikan rangsang atau persepsinya ke dalam suatu pola atau bentuk secara keseluruhan.

Selanjutnya, Rusli (1988:130) menyatakan bahwa drill berguna untuk memperlancar murid melakukan lebih banyak respons yang tepat dan benar. Menurut Oxendine (1999:83), ada tiga hal penting dari aktivitas siswa untuk mengolah rangsang yang diterimanya, yaitu: (1) menghubungkan satu rangsang dengan yang lain; (2) merumuskan sementara tentang kaitan antara cara (alat) dan tujuan; (3) berperilaku untuk mencapai tujuan. Belajar gerak menurut teori ini adalah suatu keterampilan cabang olahraga yang dilakukan secara keseluruhan dalam cabang olahraga tersebut.

Dalam belajar gerak secara spesifik dikembangkan dua teori belajar gerak, yaitu yang dikembangkan oleh Adam dan Schmidt. Teori Adam disebut dengan teori belajar gerak sitem tertutup (close-loop theory), dan Schmidt disebut teori skema (Schema Theory).

Menurut Schmidt (1998:479), konsep utama teori Adam adalah rujukan benar atau salah. Respons gerakan yang telah dilakukan siswa dibandingkan dengan suatu kriteria. Mekanisme rujukan berlangsung dalam sistem tertutup, kemudian sebagai sebuah sistem yang ter- 
buka mengirimkan semua informasi yang diperlukan untuk memulai suatu gerakan. Menurut Adam (Schmidt, 1998: 480), jika seseorang melaksanakan tugas gerak, akan menghasilkan rangsang umpan balik intrinksik. Rangsang ini meninggalkan jejak dalam sistem persyarafan yang disebut dengan jejak perseptual. Setiap respons menghasilkan jejak yang semakin lama mendekati target yang diinginkan. Setiap kali siswa melakukan latihan atau percobaan suatu gerakan, maka semakin kuat jejak perseptual dan berarti semakin berkurang kemungkinan kesalahan yang terjadi. Siswa secara aktif menggunakan pengetahuan tentang hasil dalam kaitannya dengan jejak perseptual untuk melakukan gerakan yang semakin cermat. Setelah suatu gerakan dilakukan, siswa akan membandingkan umpan balik yang diterimanya dengan jejak perseptual, dan perbedaan yang terjadi merupakan kesalahan (error) yang akan ditanggapi. Pengarahan gerak ke arah yang dituju dapat menghasilkan perubahan karena umpan balik terusmenerus menambah jejak perseptual.

Robb (1992:24) learning theories are classified into three broad categories. This categories are: (1) association; (2) cognitive; and (3) cybernatic. Teori belajar diklasifikasikan ke dalam tiga kategori. Ketiga kategori tersebut adalah asosiasi (association), kognitif (cognitive), dan sibernatik (cybernatic). Menurut Robb (1992: 24), association theorist stress the significance of resposes the organism makes and the association or conection of the response to the stimuli. Para ahli teori assosiasi menekankan signifikansi respons yang dibuat oleh siswa dan asosiasi atau ko- neksi respons terhadap stimulus. Para ahli menetapkan pentingnya peran pengalaman utama atau khusus dan penguatan respons-respons. Cognitive psychologiests believe that learning is a process through which the leaner discovers and understands relationsips. Sensory experiences arouse by external situation are organized into meaningfull significance. Learning results from a change in the way one perceives his environt as the result of insigh.

Adapun Sibernatik merupakan bidang baru dalam konstruk teori belajar gerak yang diungkapkan oleh Robb. Cybernatic theory attempt to explain the intricate working of the brain and learning by comparing the mechanics and operation of the nervous system to that complex electronic computers. Teori sibernatik mencoba untuk menjelaskan kerja yang rumit dari otak dan belajar dengan membandingkan cara kerja (mekanisme kerja) sistem syaraf dengan sistem elektronik komputer yang kompleks. Umpanbalik (Feedback) merupakan aspek yang sangat penting dalam kondisi belajar menurut teori sibernatik, lebih penting bentuk penguatan atau pengetahuan tentang hasil. Umpan balik dikenal sebagai informasi kesalahan (error information) dan merupakan variabel yang penting dalam mengontrol dan mengatur perilaku manusia.

Selaras dengan Robb, Oxendine (1996:90) mengemukakan pendapatnya bahwa: The cybernatic theory is based on the concept that information, or feedback, receive during performance influences on going behavior in that particular task. Teori sibernatik berdasarkan pada konsep bahwa informasi atau umpanbalik yang diterima selama penampilan ge- 
rak mempengaruhi perubahan perilaku dalam tugas khusus tersebut atau dalam tugas gerak khusus tersebut.

Menurut Vannier dan Gallahue (1998:182), dorongan untuk belajar adalah alami, para muda memiliki dorongan yang sangat kuat dan besar sekali. Belajar berarti menemukan, mencari, dan membuat penyesuaian yang memuaskan dengan lingkungan baru. Sebagian besar belajar diperoleh melalui kesalahan dan kemudian belajar dari kesalahan untuk mendapatkan kesuksesan. Teori belajar yang dapat diterima menurut Vannier dan Gallahue (1998: 182) adalah teori belajar conditioning, conectionism, dan field theory, semua teori belajar tersebut menekankan belajar dengan melakukan dan belajar melalui pengalaman.

Pendapat tentang belajar dikemukakan juga oleh Singer (1980:1, 8) yang menyatakan bahwa ada tiga komponen dalam belajar gerak, yang bergerak dan beroperasi secara dinamis. Ketiga komponen tersebut, yaitu siswa, aktivitas, dan situasi atau kondisi lingkungan. Ketiga komponen tersebut saling berinteraksi untuk menghasilkan perubahan perilaku. Belajar mengakibatkan perubahan dalam diri pribadi dan selalu terefleksi dalam perilaku yang dapat diamati. Perubahan tersebut secara relatif permanen sebagai konsekuensi dari pengalaman atau latihan.

Dalam pembelajaran pendidikan jasmani, proses belajar motorik tidak dapat dipisahkan dari proses mengajar motorik. Pembelajaran pada hakikatnya adalah merupakan upaya untuk menjadikan murid belajar dan mengajar yang baik pada prinsipnya adalah meng- ajari bagaimana siswa mengajari dirinya sendiri atau mengajari bagaimana siswa belajar dengan baik.

Beberapa ahli mengemukakan pendapatnya tentang pengertian pembelajaran pendidikan jasmani. Nichold (1986: 61) berpendapat bahwa:

"In learning motor skills children generally pass three stages of learning. In the first stage they begin to grasp an understanding of the squence of the task, how body parts are use, and control of space and movement qualities for successful performance. The second stage is the practice stage in which children refine pattern, correcting errors as needed. The third stage involves mastery learning and relatively automatic performance in which the skill is habituated."

\section{Hakikat Pendekatan Pembelajaran dengan Gaya Mengajar Pemecahan Masalah}

Pembelajaran merupakan sebuah konsep yang terkait dengan proses belajar dan mengajar. Dalam bidang pendidikan, istilah belajar-mengajar akhir-akhir ini lebih populer dengan istilah pembelajaran. Dalam bidang kegiatan pembelajaran penjas, terkait dengan perilaku motorik. Untuk mempelajari perilaku motorik dapat dilakukan dengan berbagai pendekatan. Pendekatan yang dapat dilakukan dalam mempelajari perilaku motorik adalah pendekatan psikologis, yang mencakup psikologi behaviorisme, psikologi kognitif, dan pendekatan fisiologi-psikologis. Psikologi behaviorisme menitikberatkan perhatiannya pada hubungan antara stimulus dan respons. Psikologi kognitif menekankan pada upaya memanipulasi lingkungan dan khususnya pada proses neurofisiologis. Pendekat- 
an fisiologi-psikologis memperhatikan proses atau gejala fisiologis yang terjadi yang melandasi perilaku manusia. Titik perhatiannya adalah pada gejala neurofisiologis dalam proses berpikir, belajar, mempersepsi, dan motivasi. Dalam bidang psikilogi, perilaku manusia dapat diartikan sebagai kegiatan manusia yang mencakup mengindera, mempersepsi, memperhatikan, belajar, dan bergerak. Belajar dan bergerak merupakan merupakan bagian dari kajian pendidikan jasmani, termasuk didalamnya proses belajar-mengajar. Istilah lain proses belajar mengajar penjas disebut juga proses pembelajaran penjas. Menurut Sukintaka (2001:29), pembelajaran mengandung pengertian, bagaimana para guru mengajarkan sesuatu kepada siswa dan terjadi peristiwa bagaimana siswa mempelajarinya. Dalam proses pembelajaran ada proses belajar dan ada proses mengajar.

Sebagaimana telah disebutkan di atas, bahwa proses pembelajaran penjas berkaitan dengan proses belajar motorik dan proses mengajar keterampilan motorik. Proses belajar motorik pada prinsipnya adalah proses pertautan antara stimulus dan respons motorik sehingga untuk memudahkan menganalisis kegiatan pembelajaran penjas digunakan model komunikasi. Dalam model komunikasi, ada informasi yang disampaikan melalui suatu media komunikasi kepada pihak lain dan pihak lain akan memberikan respons. Dalam hal ini pemberi informasi adalah guru dan penerima informasi adalah siswa.

Proses pembelajaran penjas melibatkan hubungan antar orang yang berkomunikasi. Berdasarkan hal ini, maka teori komunikasi dapat diterapkan agar proses pembelajaran penjas dapat berlangsung dengan baik, efektif dan efisien. Agar proses pembelajaran berlangsung secara efektif dan efisien, perlu dipahami unsur-unsur komunikasi dalam proses pembelajaran penjas. Lewis (Rusli, 1988:393) menyatakan bahwa komunikasi terdiri dari proses di mana seseorang berusaha mengurangi sekecil mungkin faktor ketidak pastian atau ketidak jelasan yang terkandung dalam isi pesan. Hal ini berarti faktor persepsi, kecermatan dari pihak penyampai dan penerima informasi/pesan, dan interaksi timbal balik merupakan unsur penting dalam komunikasi.

Kesiapan guru sebagai pemberi pesan atau informasi dan kesiapan murid sebagai penerima pesan atau informasi merupakan unsur yang menentukan keberhasilan proses pertautan stimulus respons. Kesiapan guru mencakup kemampuan merencanakan pesan yang berupa materi pelajaran yang akan disampaikan, kemampuan menyampaikan pesan yang berupa keterampilan berbicara, menulis, menggunakan media, keterampilan menampilkan demonstrasi berbagai teknik dalam cabang olahraga, dan keterampilan mengelola kelas. Kesiapan murid mencakup kemampuan untuk menerima pesan atau materi pelajaran, dalam hal ini tergantung pemahaman dan latar belakang pengetahuan yang dimiliki oleh murid, kesiapan fisik dan psikologis.

Menurut Nichols (1996:31), effective theaching result from the combination of carefully planned and organized learning experiences and the teacher ability to carry 
the lesson through to successful completion. Mengajar yang efektif diperoleh dari kombinasi perencanaan yang hati-hati dan pengalaman belajar terorganisasi serta kemampuan guru untuk membawa pelajaran kepada keberhasilan yang sempurna. Secara konseptual guru penjas merupakan fasilitator yang membantu siswa untuk belajar bagaimana belajar. Menurut Dauer dan Pangrazy (1996:65), the teacher as an educator is the most important single factor in the educational process. Guru merupakan faktor penting dalam proses pembelajaran dan tidak ada satu cara yang paling baik dalam mengajar, serta perlunya diagnose pendekatan preskriptif untuk memonitor kemajuan dan elemen-elemen dalam pelajaran. Gabbard, LeBlance, Lowy (1996:119) menambahkan bahwa variabel yang sangat penting dalam lingkungan belajar adalah guru. Guru yang berpakaian layak dan rapi, percaya diri, mendudukan kebenaran dengan baik, konsisten, bersahabat (friendly), terbuka (fair), dan kompeten dalam bidangnya akan mendapatkan respek yang alami oleh para muridnya. Siswa akan merasa tenang dan aman dengan keadaan lingkungan yang menyenangkan dan aman. Kemajuan perolehan keterampilan motorik, kognitif, dan afektif yang dipersiapkan dengan baik, diharapkan dapat mencapai keinginan yang diharapkan.

Ada tiga hal yang perlu dipahami dalam proses pembelajaran penjas. Pertama, guru sebagai seorang pendidik merupakan faktor tunggal yang sangat penting dalam proses pendidikan, khususnya dalam pemilihan gaya mengajar yang sesuai dengan kebutuhan anak.
Kedua, tidak ada hanya satu cara yang terbaik dalam mengajar. Secara alami, satu pendekatan akan menjadi lebih layak tergantung pada tujuan yang ingin dicapai. Ketiga, perlunya kepandaian mengamati kelas untuk dapat memahami dan menerapkan dengan tepat pendekatan pembelajaran yang sesuai dengan kebutuhan anak, terutama yang berkaitan dengan minat dan pertumbuhan serta perkembangannya.

Menurut Moston (Dauwer dan Pangrazy, 1997:68-73), terdapat sembilan gaya mengajar dalam penjas. Salah satu gaya mengajar tersebut adalah gaya mengajar pemecahan masalah (problem-solving style). Menurut Dauwer dan Pangrazy (1997:72), gaya mengajar pemecahan masalah mencakup masukan (input), pemilihan refleksi, dan respons. Permasalahan harus disusun tanpa adanya jawaban. Permasalahan disusun dari yang mudah ke yang sukar. Tingkat kesukaran ditentukan berdasarkan cara pemikiran yang digunakan untuk memecahkan masalah.

Menurut Dauwer dan Pangrazy (1997: 73), langkah-langkah dalam gaya mengajar pemecahan masalah meliputi: (1) presenting the problem, mahasiswa diberi permasalah dalam bentuk pernyataan yang menuntut pemikiran dan refleksi gerak; (2) determining prosedure, mahasiswa memikirkan langkah-langkah atau cara-cara melakukan gerakan dalam kelompoknya; (3) experimentation and eksplorasi, mahasiswa mencoba berbagai cara yang dapat dilakukan dalam melaksanakan gerakan sesusi dengan temuannya; (4) observation, evaluation, and discussion, tiap mahasiswa dalam 
kelompoknya harus menawarkan hasil kerjanya dan mengobservasi hasil kerja tiap individu dalam kelompoknya dan mendiskusikannya; (5) refinning and expanding, setelah diperoleh cara melakukan gerakan hasil diskusi kelompok, tiap mahasiswa harus diberi kesempatan melaksanakan cara melaksanakan gerakan tersebut.

Mahasiswa harus memahami bahwa masalah tersebut dapat dipecahkan dan menemukan solusi pemecahannya. Salah satu hal yang cukup sulit dalam pendekatan ini adalah mendesain masalah yang sesuai antara tingkat kesulitan gerak dan tingkat kematangan gerak mahasiswa.

\section{Hakikat Kemampuan Kognitif}

Menurut teori Piaget (Wadsworth, 1984:9-17), aksi kognitif adalah aksi organisasi dan adaptasi terhadap lingkungan. Prinsip dasar perkembangan kognitif sama dengan proses perkembangan secara biologis. Kedua proses adaptasi dan organisasi tersebut merupakan proses yang tidak dapat dilihat secara terpisah. Dalam pengamatan secara biologi, organisasi merupakan bagian dari proses adaptasi yang merupakan dua proses yang saling mengisi dalam satu mekanisme. Organisasi merupakan aspek internal dari suatu siklus dimana adaptasi merupakan aspek eksternal yang menyusunnya. Untuk memulai memahami proses organisasi intelektual dan adaptasi intelektual, ada empat konsep yang perlu dipahami yaitu, schema, assimilation, accomodation, dan equilibration. Konsep ini untuk menjelaskan mengapa dan bagaimana perkembangan mental terjadi.
Schema adalah penstrukturan suatu secara kognitif dalam proses mengadaptasi dan mengorganisasi lingkungan. Contoh dalam aktivitas ini adalah anak membuat konsep dalam pikiranya terhadap suatu objek, misalnya binatang sapi, membuat skema tentang sapi mengenai kakinya ada empat, lebih besar dari kucing, jinak, dan sebagainya.

Assimilastion adalah proses kognitif dimana individu mengintegrasikan persepsi, motorik, atau konsep baru ke dalam sekema yang sudah ada atau pola perilakunya. Contoh aktivitas ini adalah individu melihat sesuatu objek yang baru atau melihat (mengamati) lagi objek lama yang sudah ada sekemanya dalam pikirannya. Apa yang diamati oleh individu tersebut akan disesuaikan dengan sekema yang sudah ada dalam pikirannya.

Accomodation adalah pertentangan terhadap stimulus baru. Individu dapat membuat skema baru terhadap stimulus baru atau individu memodifikasi stimulus baru tersebut. Jadi, akomodasi adalah penciptaan skema baru atau modifikasi dari sekema lama.

Equilibrition adalah proses penyeimbangan antara asimilasi dan akomodasi. Hal ini adalah penting untuk interaksi yang efisien terhadap lingkungannya. Keseimbangan adalah keadaan seimbang antara asimilasi dan akomodasi. Equilibrasi adalah proses perubahan dari tidak seimbang menjadi seimbang.

Selanjutnya, teori Piaget tentang perkembangan kognitif menyatakan bahwa inteligensi memiliki tiga komponen, yaitu isi (content), fungsi (func- 
tion), dan struktur (structure). Isi adalah apa yang diketahui oleh anak yaitu perilaku, sensori motor, dan konseptual yang dapat diamati yang merupakan refleksi dari aktivitas intelektual. Fungsi adalah karakteristik dari proses aktivitas intelektual asimilasi dan akomodasi yang tetap dan kontinyu. Struktur adalah berkaitan dengan proses penstrukturan atau pengorganisasian dalam membuat skema.

Kemampuan kognitif merupakan salah satu aspek tujuan yang hendak dikembangkan dalam setiap proses pendidikan. Gabbard, LeBlance, dan Lowy (1987:6) menyatakan, "Cognitive development, primarily composed of the thought processes, such as problem solving, comprehension, and creativity". Kemampuan kognitif adalah merupakan proses berpikir seperti memecahkan masalah, pemahaman, dan kreativitas. Monks, Knoers, dan Siti Rahayu Haditono (1992: 202) menyatakan bahwa kognitif adalah pengertian yang luas mengenai berpikir dan mengamati, jadi tingkah laku yang mengakibatkan orang memperoleh pengertian atau yang dibutuhkan untuk menggunakan pengertian. Menurut Wuest dan Bucher (1995:4041), perkembangan pengetahuan dan pemahaman adalah merupakan tujuan yang penting dari penjasor. Belajar dalam aktivitas jasmani melibatkan proses kognitif. Secara kognitif, siswa dalam hal ini mahasiswa harus menganalisis kinerjanya, mensintesis informasi, dan menerapkannya dalam situasi yang baru.

Perkembangan kognitif adalah merupakan proses adaptasi terhadap lingkungannya. Menurut teori Piaget (Wads- worth, 1984:20-33), proses adaptasi dimulai sejak awal, yaitu sejak kelahiran melalui latihan sensori motor. Sumber utama untuk adaptasi adalah keseimbangan. Pikiran-pikiran anak tidak akan berkembang sampai siswa menemukan atau melihat nilai intelektual terhadapnya, yaitu sampai pengalaman siswa tidak seimbang. Adaptasi terjadi ketika ada kebutuhan atau nilai dalam individu. Faktor-faktor yang ada dalam perkembangan kognitif adalah kematangan, pengalaman, interaksi sosial, dan keseimbangan.

Gallahue (Gabbard, LeBlance, dan Lowy, 1987:7) menyatakan bahwa terdapat dua aspek pokok dalam perkembangan kemampuan kognitif yang berkaitan dengan program gerak (movement program), yaitu konsep-konsep persepsi motorik dan perkembangan dan penguatan konsep-konsep akademik. Meskipun hubungan langsung antara aktivitas motorik dan kemampuan akademik tidak kuat, tetapi implikasi hubungan tidak langsung sangat kuat. Pengalaman gerak menstimulasi motivasi dan membantu perkembangan konsep diri secara positif, di mana kedua faktor tersebut merupakan faktor lingkungan yang membantu dalam belajar.

MenurutZaichkowsky dan Martinek (Gabbard, LeBlance, dan Lowy, 987: 36), jika guru ingin meningkatkan keterampilan kognitif melalui pengalamangerak, pengalaman-gerak tersebut harus secara khusus disusun untuk mengembangkan persepsi, mendorong interaksi sosial, dan merangsang kognitif. Pengalaman gerak sebagai berikut. Pertama, penggunaan permainan tersebut 
atau aktivitas gerak yang lain harus mendorong adanya problem solving, anak memperoleh kesempatan berpikir kreatif dan logis, pengembangan perhatian dan ingatan. Kedua, dasar dari perkembangan kognitif pada anak-anak adalah persepsi. Aktivitas gerak merangsang mekanisme persepsi tubuh, sebagaimana mengembangkan kesadaran tubuh terhadap lingkungannya, ruang, waktu, dan kekuatan. Ketiga, partisipasi dalam program gerak dapat meningkatkan konsep diri pada anak. Guru harus mengenal karakteristik anak secara fisik maupun emosinya.

Dalam taksonomi Bloom (Suharsimi A, 1990: 113-115), ranah kognitif berturut-turut adalah pengenalan (recognition), pemahaman (comprehention), penerapan (application), analisis (analysis), sintesis (synthesis), dan evaluasi (evaluation). Dalam penelitian ini, kemampuan kognitif yang akan dikembangkan adalah kemampuan mahasiswa dalam mengenal materi senam artistik dasar, memahaminya, dan mampu melak- sanakan gerakan tersebut. Selanjutnya mahasiswa diharapkan memiliki kemampuan untuk menganalisis gerakan dalam senam artistik, mensistesis dan mampu melakukan evaluasi. Kemampuan kognitif tersebut selanjutnya dapat diamati sebagai kemampuan mahasiswa untuk memahami gerakan, dan menyusunnya dalam bentuk perencanaan program pembelajaran dan mengimplementasikan bersama kelompoknya, dan mengevaluasi keberhasilan dalam proses pembelajarannya.

\section{METODE}

Metode yang digunakan dalam penelitian ini adalah penelitian tindakan kelas model Kemmis dan Taggart, dan dilaksanakan selama 1 semester. Subjek penelitian adalah mahasiswa PJKR Kelas B yang mengikuti (mencantumkan dalam KRS) kuliah Dasar Gerak Senam Semester Pertama Tahun Akademik 2008/2009. Tempat penelitian di Hall Senam FIK-UNY. Bentuk desain dari Kemmis \& Taggart seperti berikut.

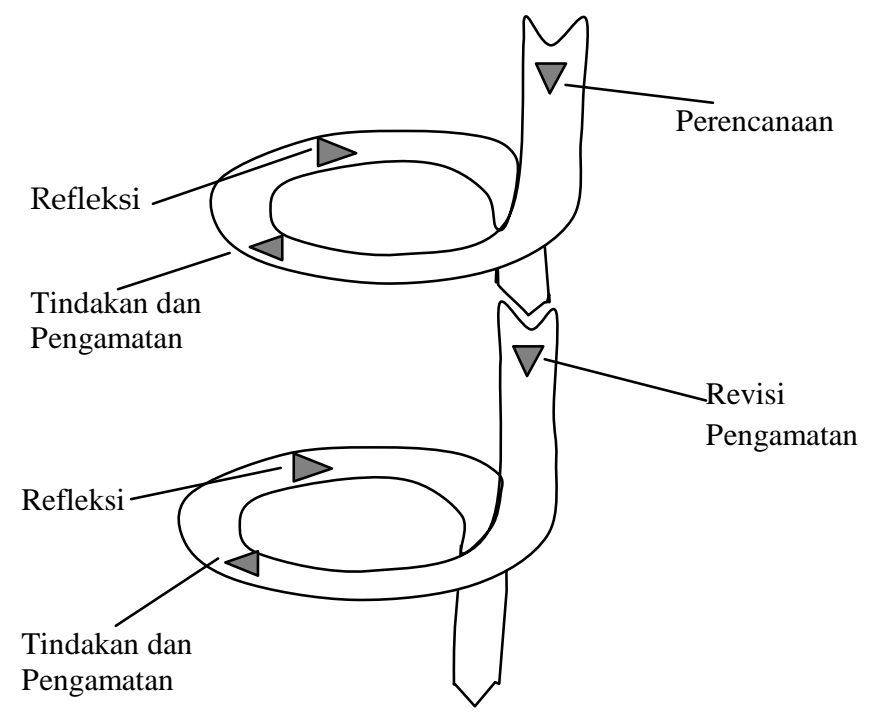


Model ini pada hakikatnya merupakan perangkat-perangkat atau untaianuntaian dengan satu perangkat terdiri dari empat komponen, yaitu perencanaan, tindakan, pengamatan dan refleksi. Untaian-untaian tersebut sebagai suatu siklus. Oleh karena itu, pengertian siklus di sini adalah putaran kegiatan yang terdiri dari perencanaan, tindakan, observasi dan refleksi.

Dalam penelitian ini dilaksanakan dalam satu siklus tindakan. Terdiri dari 12 kali tatap muka. Pendekatan pembelajaran dengan gaya mengajar pemecahan masalah diimplementasikan, selanjutnya dievaluasi, dan direfleksikan untuk tindakan berikutnya pada semester mendatang untuk kelas yang berbeda.

Pembelajaran senam artistik dilaksanakan dalam 12 kali pertemuan (12 kali tatap muka), setiap pertemuan 2 jam perkuliahan (100 menit). Pertemuan pertama dosen menjelaskan tentang materi senam, dan yang harus dilakukan mahasiswa dalam proses menguasai keterampilannya dan kemampuan kognitif apa yang harus dilakukan. Materi senam terdiri dari 10 nomor gerakan yaitu: (1) kayang; (2) berdiri atas tangan; (3) guling depan; (4) guling belakang; (5) loncat harimau; (6) meroda; (7) round off; (8) lenting tangan (hand-spring); (9) guling lenting (rollkip); (10) back extention. Nomor tersebut merupakan teknik keterampilan gerak senam artistik yang harus dikuasai mahasiswa. Mahasiswa menyusun rencana pembelajaran berdasarkan penjelasan dari dosen. Materi tersebut disusun dalam bentuk gambar, penjelasan tek- nik gerak, dan pokok-pokok yang harus diperhatikan dalam belajar teknik gerak senam artistik. Rancangan pembelajaran yang telah disusun diperiksa dosen sebelum dilaksanakan dalam proses pembelajaran. Mahasiswa membentuk kelompok beranggotakan 10 mahasiswa tiap kelompok. Tiap mahasiswa memperoleh satu materi atau satu nomor senam artistik untuk dipelajari dan diimplementasikan dalam pembelajaran dalam kelompoknya. Selanjutnya, mahasiswa melaksanakan pembelajaran senam artistik sesuai kelompoknya dengan bimbingan lembar yang telah disusunnya, dan bagaimana melaksanakan pembelajaran dan mengobservasinya. Setiap pertemuan dua mahasiswa tampil melaksanakan proses pembelajaran masing-masing selama 50 menit. Dosen membimbing mahasiswa dengan berkeliling mengamati proses pembelajaran yang dilakukan mahasiswa secara berkelompok. Hasil belajar mahasiswa dievaluasi berdasarkan laporan dari tiap mahasiswa dalam kelompoknya dan hasil observasi dosen. Evaluasi pelaksanaan proses pembelajaran senam artistik dilakukan terhadap kemampuan mahasiswa dalam mensistesis gerakan menjadi tahap-tahap belajar gerak senam, mengimplementasikan dalam pembelajaran dan mengevaluasi pelaksanaan pembelajaranya. Kemampuan kognitif mahasiswa dalam menganalisis gerakan senam artistik dan menyusun perencanaan proses pembelajaran senam artistik dan hasil belajarnya (kemampuan psikomotorik) menjadi fokus utama dalam pengamatan dan penilaian. Monitoring: untuk 
mengobservasi dan mengevaluasi proses pembelajaran berlangsung, melibatkan 2 dosen lain sebagai tenaga ahli untuk mengamati dan mengevaluasi proses pembelajaran. Observasi dilakukan terhadap semua aspek yang muncul dalam setiap tindakan yang dilakukan. Observasi terutama pada keterlibatan mahasiswa dan dosen dalam diskusi, kemampuan kognitifnya dalam menganalisis dan tingkat perkembangan perolehan keterampilan gerak selama pembelajaran berlangsung. Kemampuan kognitif meliputi: aplikasi, yaitu kemampuan menyusun atau merencanakan program pembelajaran gerakan dalam senam artistik. Analisis yaitu kemampuan menguraikan gerakan senam menjadi tahap-tahap gerakan yang dapat diuraikan dalam perencanaan pembelajaran secara metodis.
Sintesis yaitu kemampuan menyusun kembali urutan dan tahap-tahap gerakan berdasarkan tingkat kesulitan dan konsep pentingnya pengalaman gerak. Evaluasi yaitu kemampuan untuk menilai keberhasilan dalam melaksanakan gerakan senam secara mandiri. Hasil observasi dan evaluasi didiskusikan bersama untuk saling memberi masukan terhadap hal yang kurang baik untuk diperbaiki pada penampilan berikutnya. Teknik analisis data adalah deskriptif kuantitatif.

\section{HASIL DAN PEMBAHASAN}

Ringkasan hasil penilaian pembelajaran senam dalam hal keterampilan dan kemampuan kognitif mahasiswa dapat dilihat pada Tabel 1 dan Tabel 2 berikut.

Tabel 1: Ringkasan Data Hasil Penilaian Kemampuan Kognitif dalam Senam

\begin{tabular}{clcc}
\hline No & \multicolumn{1}{c}{ Sumber Stastistik } & Awal & Akhir \\
\hline 1. & Skor Tertinggi & 6,75 & 7,25 \\
2. & Skor Terendah & 4,25 & 5,00 \\
3. & Rata - rata & 5,84 & 6,00 \\
4. & Standar Deviasi & 1,32 & 1,42 \\
\hline
\end{tabular}

Tabel 2: Ringkasan Data Hasil Penilaian Keterampilan dalam Senam

\begin{tabular}{clcc}
\hline No & \multicolumn{1}{c}{ Sumber Stastistik } & Awal & Akhir \\
\hline 1. & Skor Tertinggi & 5,17 & 6,20 \\
2. & Skor Terendah & 7,00 & 7,50 \\
3. & Rata - rata & 6,40 & 7,20 \\
4. & Standar Deviasi & 2,16 & 2,23 \\
\hline
\end{tabular}

Berdasarkan hasil observasi dan evaluasi proses pembelajaran senam dengan pendekatan pemecahan masalah, kemampuan kognitif mahasiswa mengalami peningkatan. Hal ini dapat dilihat dari hasil observasi dan evaluasi yang dilakukan pada proses pembelajaran pertama dan ke dua mengalami perubahan. Rata-rata skor kemampuan kognitif mahasiswa setelah proses pembelajaran pertama 5,84 meningkat menjadi rata-rata 6,00 setelah proses 
pembelajaran yang ke dua. Keterampilan gerak mahasiswa juga mengalami peningkatan. Keterampilan gerak senam mahasiswa setelah proses pembelajaran pertama rata-ratanya 6,40. Meningkat menjadi rata-rata 7,20 setelah proses pembelajaran yang ke dua.

\section{PEMBAHASAN}

Berdasarkan data hasil pengukuran kemampuan kognitif, rata-rata skor kemampuan kognitif mahasiswa dalam senam artistik 6,00 menunjukan peningkatan skor. Singer $(1980: 1,8)$ menyatakan bahwa ada tiga komponen dalam belajar gerak, yang bergerak dan beroperasi secara dinamis. Ketiga komponen tersebut, yaitu siswa, aktivitas, dan situasi atau kondisi lingkungan. Siswa atau mahasiswa menunjukan adanya dorongan atau motivasi untuk menunjukan kinerja kognitif yang baik dengan menuangkannya dalam bentuk rancangan program pembelajarannya. Mahasiswa tertantang untuk memecahkan problem pembelajarannya sendiri dan mengimplentasikannya dalam bentuk membelajarkan kepada teman dalam kelompoknya. Hasil belajar sendiri dan teman dalam kelompoknya dapat dirasakan langsung dan menjadi bahan diskusi, sehingga dapat dijadikan masukkan dalam program pembelajaran yang ke dua. Ketiga komponen tersebut saling berinteraksi untuk menghasilkan perubahan perilaku yang positif dalam belajar. Proses pembelajaran tersebut mengakibatkan perubahan dalam diri mahasiswa dan selalu terefleksi dalam perilaku belajar yang baik dan dapat diamati. Perubahan tersebut secara relatif mempengaruhi kemampuan kogni- tifnya sebagai akibat dari pengalaman belajarnya bersama-sama dengan pengalaman belajar teman dalam kelompoknya.

Pendekatan pembelajaran pemecahan masalah menciptakan kondisi lingkungan belajar yang memungkinkan intensitas belajar mahasiswa dalam belajar memahami karakteristik gerak menjadi lebih kondusif sehingga hasilnya pun juga baik. Dalam proses pembelajaran juga terlihat mahasiswa termotivasi untuk melakukan diskusi dan melakukan latihan atau mengulang aktivitas geraknya dalam senam.

Pendapat senada disampaikan oleh Vannier dan Gallahue (1998: 182) yang menyatakan bahwa dorongan untuk belajar adalah alami, para muda memiliki dorongan yang sangat kuat dan besar sekali. Belajar berarti menemukan, mencari, dan membuat penyesuaian yang memuaskan dengan lingkungan baru. Sebagian besar belajar diperoleh melalui kesalahan dan kemudian belajar dari kesalahan untuk mendapatkan kesuksesan. kesemua teori belajar tersebut menekankan belajar dengan melakukan dan belajar melalui pengalaman. Lingkungan yang menyenangkan karena berdiskusi dan memecahkan masalah merupakan karakteristik mahasiswa, yang memungkinkan mereka memperoleh kesempatan untuk berkembang dengan baik. Hal ini mendorong mahasiswa untuk selalu mengulang latihanya setiap saat ada peluang. Frekuensi mengulang latihan keterampilan gerak dalam senam menjadi banyak. Kesempatan yang banyak menyebabkan keterampilan belajarnya meningkat. Hal ini sesuai dengan pendapat 
Lockhart (1980:254-256) untuk mendapatkan keterampilan memerlukan latihan, tetapi latihan tidak otomatis menghasilkan kecakapan yang meningkat. Latihan tidak perlu menghasilkan kesempurnaan. Kemajuan datang manakala siswa berminat untuk belajar dan mencoba untuk memperbaiki diri. Lama latihan yang menguntungkan tergantung pada kematangan, besarnya minat, latar belakang gerak atau pengalaman, dan kekompleksan hal-hal yang akan dikuasai. Pola gerakan yang rumit tidak dikuasai secara tiba-tiba. Pelajaran gerak atau motorik merupakan suatu proses lambat yang memerlukan latihan untuk mengendalikan aspek urut-urutan dan aspek tubuh dalam suatu gerakan dan untuk menjaga kuantitas dan mutu gerakan. Hal ini diperlukan untuk menghasilkan gerak yang baik koordinasinya dan efektif. Belajar dan motivasi untuk belajar memerlukan pengetahuan tentang hasil yang akan diperoleh. Kondisi ini dapat diperoleh mahasiswa dalam pembelajaran dengan pendekatan pemecahan masalah. Mahasiswa memperoleh kesempatan memenuhi keinginannya untuk mengetahui bagaimana kemajuan yang diperoleh dalam belajarnya. Berdasarkan kenyataan, proses pembelajaran berlangsung, dalam kondisi dengan baik sehingga dapat menyebabkan keterampilan gerakan yang dikuasainya menjadi baik.

Berdasarkan hasil pengukuran (penilaian) dan penghitungan keterampilan gerak senam mahasiswa, rata-rata skor keterampilan gerak senam artistik mahasiswa tergolong baik 7.02. Jika dikonversikan dengan standar penilaian tergolong B- .Nilai ini masih diatas nilai kemampuan kognitif mahasiswa.

\section{PENUTUP}

\section{Kesimpulan}

Berdasarkan hasil perhitungan dan analisis hasil penelitian dapat disimpulkan bahwa: (1) pendekatan pembelajaran senam artistik dengan gaya mengajar pemecahan masalah dapat meningkatkan kemampuan kognitif Mahasiswa Program Studi PJKR 2008 Ratarata skor kemampuan kognitif mahasiswa setelah proses pembelajaran pertama 5,84 meningkat menjadi rata-rata 6,00 setelah proses pembelajaran yang ke dua; (2) keterampilan gerak mahasiswa juga mengalami peningkatan. Keterampilan gerak senam mahasiswa setelah proses pembelajaran pertama rataratanya 6,40. meningkat menjadi ratarata 7,20 setelah proses pembelajaran yang ke dua.

Keberhasilan proses peningkatan pembelajaran dengan pendekatan gaya mengajar pemecahan masalah tersebut di atas secara signifikan memberikan dampak yang besar terhadap mata kuliah yang lain di Jurusan PJKR FIKUNY. Pendekatan mengajar senam artistik tersebut dapat diseminisasikan dan diterapkan untuk pendekatan matakuliah yang lain yang memiliki karakteristik sama dengan senam artistik, yaitu teknik keterampilan gerak yang kompleks. Dengan demikian, memberikan manfaat yang besar bagi pengembangan jurusan dan perbaikan output dan outcome. 


\section{Saran}

- Untuk siklus kedua harus diupayakan kesesuaian antara alat dan fasilitas dengan jumlah mahasiswa.

- Banyaknya ulangan latihan menentukan perolehan keterampilan. Olah karena itu, kesempatan mengulang latihan harus dikondisikan dalam pembelajaran.

\section{UCAPAN TERIMA KASIH}

Terima kasih saya ucapkan kepada Redaktur Jurnal Cakrawala Pendidikan yang telah memberi input untuk penyempuraan artikel ini. Terima kasih juga diucapkan kepada semua staf Jurnal Cakrawala Pendidikan.

\section{DAFTAR PUSTAKA}

Arikunto, Suharsimi. 1996. Penyusunan Proposal dalam Penelitian Kelas (CAR). Yogyakarta: Lemlit IKIP Yogyakarta.

Baley, James A; Field, David A. 1996. Physical Education and Physical Educator. Boston: Allyn and Bacon, Inc.

Carl Gabbard, LeBlance, Elizabeth, Lowy Susan. 1997. Physical Education For Children. Building Foundation, Englewood Cliffs, New Jersey: Prentince-Hall, Inc.

Corbin, Charles B. 1980. A textbook of motor development. $2^{\text {nd }}$ Edition. Dubuque, Iowa: Wm. C. Brown Company Publishers.

Dauer, Victor; P. Pangrazy; Robert, P. 1997. Dynamic physical education for elementary school children. New York: Macmillan Publishing Company.

Gabbard, Carl; LeBlance, Elizabeth; Lowy, Susan. 1997. Physical Education for Children, Building Foundation. Englewood Cliffs: Prentice-Hall, Inc.

Ganong, William F. 1999. Buku Ajar Fisiologi Kedokteran. Alihbasa: dr. M. Jauhari Widjajakusumah. Jakarta: Penerbit Buku Kedokteran ECG.

Lochart, Ailleene. 1996. Practices and Principles Governing Motor Learning of Children. Dubuque: Wm. C. Brown Company Publisher.

Lutan, Rusli. 1988. Belajar Keterampilan Motorik: Pengantar Teori dan Metode. Jakarta: Departemen Pendidikan dan Kebudayaan Direktorat Jenderal Pendidikan Tinggi, Proyek Pengembangan Lembaga Pendidikan Tenaga Kependidikan Jakarta.

Mahendra, Agus. 2001. Pembelajaran Senam, Jakarta: Departemen Pendidikan Nasional.

Nichols, Beverly. 1996. Moving and Learning. The Elementary School Physical Education Experience. St. Louiss, Missouri: Times Mirror/ Mosby College Publishing. 
Oxendine, Joseph B. 1996. Psychology of Motor Learning. Englewood Cliffs: Prentice-Hall Inc.

Robb, Margaret D. 1996. The Dynamics of Motor Acquisition. Englewood Cliffs, New Jersey: Prentice.

Schmidt, Richard A. 1988. Motor Control and Learning. A Behavior Emphasis. Illinois: Human Kinetics Publisher.

Seefeldt, Carol. 1990. Teaching Young Children. Englewood Cliffs: Prentice-Hall.

Singer, Robert N. 1999. Motor Learning and Human Performance. An Application to Motor Skill and Movement Behaviors. New York: Macmillan publishing Co. Inc.
Sukintaka. 1993. Teori Bermain. Jakarta: Depdikbud.

Tim PUDI Dikdasmen Lemlit-UNY. 2007. Penelitian Tindakan Kelas. Bahan Diklat Profesi Guru. Yogyakarta: Tim PUDI Dikdasmen Lemlit-UNY.

Vannier, Gallahue. 1998. Teaching Physical Education in Elementary School. Philadelhia: Saunders College Publishing.

Wadsworth, Barry J. 1984. Piaget's Theory Cognitive and Afective Development. New York: Longman Inc.

Wuest, Deborah A; Bucher Charles A. 1995. Foundation of Physical Education and Sport. New York: Mosby-Year Book, Inc. 